\title{
PERFORMANSI BIOGAS TYPE DRUM PORTABEL DENGAN VARIASI pH 6.8, 7, 7.2, 7.6, 7.8, 8
}

\author{
Syamsuri \\ Institut Teknologi Adhi Tama Surabaya (ITATS) \\ JI. Arief Rachman Hakim No. 100, Surabaya, Jawa Timur \\ Email : syamsuri@itats.ac.id
}

\begin{abstract}
Abstrak
Biogas adalah gas campuran metana $\left(\mathrm{CH}_{4}\right)$, karbondioksida $\left(\mathrm{CO}_{2}\right)$ dan gas lainnya yang didapat dari hasil penguraian material organik termasuk seperti kotoran manusia dan hewan, tumbuhan oleh bakteri pengurai metanogenik pada sebuah biodigester. Pada penelitian ini, biogas digunakan sebagai bahan bakar dengan penambahan variasi $\mathrm{pH}$ dari bahan natrium karbonat dan tawas terhadap mesin generator set gasoline yang telah dimodifikasi agar dapat bekerja menghasilkan listrik. Eksperimen ini memvariasikan $\mathrm{pH}$ slurry $6.8,7,7.2,7.4,7.6,7.8$. 8 dengan variasi beban listrik 10 watt, 15 watt, 20 watt, 25 watt, 30 watt, 35 watt, 40 watt, 45 watt dan 50 watt. Hal ini bertujuan untuk mengetahui performa daya listrik, efisiensi sistem dan torsi. Dari pengujian ini didapat semakin besar beban lampu maka semakin kecil performa daya listrik yang dihasilkan. Hasil penelitian menunjukan bahwa daya listrik terbesar dengan beban lampu 10 watt yakni 30,03 watt. Pada pengujian efisiensi sistem beban listrik semakin besar maka efisiensi sistem cenderung stabil. Efisiensi sistem terbaik dengan kadar $\mathrm{pH} 7$ dibandingkan dengan kadar $\mathrm{pH}$ lainnya. Pada pengujian torsi beban listrik semakin besar maka torsi yang dihasilkan juga besar. Pada torsi terbesar dengan kadar $\mathrm{pH} 7$ dibandingkan kadar $\mathrm{pH}$ lainnya.
\end{abstract}

Kata kunci : Variasi pH, Biogas, Daya Listrik, Efisiensi sistem, Torsi.

\begin{abstract}
Biogas is a gas mixture of methane (CH_4), carbon dioxide (CO_2) and other gases obtained from the decomposition of organic material including human and animal waste, plants by methanogenic decomposing bacteria in a biodigester. In this study, biogas is used as fuel by adding variations in the $\mathrm{pH}$ of sodium carbonate and alum to the modified gasoline generator set engine so that it can work to generate electricity. This experiment varies the slurry $\mathrm{pH}$ of $6.8,7,7.2,7.4,7.6,7.8 .8$ with a variety of electrical loads 10 watts, 15 watts, 20 watts, 25 watts, 30 watts, 35 watts, 40 watts, 45 watts and 50 watts. This aims to determine the performance of electric power, system efficiency and torque. From this test, it is found that the greater the lamp load, the smaller the performance of the electric power produced. The results showed that the largest electric power with a lamp load of 10 watts is 30.03 watts. In testing the efficiency of the system, the greater the load, the more stable the system efficiency. The best system efficiency with a pH level of 7 compared to other $\mathrm{pH}$ levels. In testing the electric load torque, the greater the greater the resulting torque. At the greatest torque with a $\mathrm{pH}$ level of 7 compared to other pH levels.
\end{abstract}

Key words: $p H$ variation, Biogas, Electricity, System efficiency, Torque. 


\section{PENDAHULUAN}

Energi merupakan bagian penting untuk menunjang aktivitas dan usaha produktif dalam menghasilkan barang dan jasa. Pertambahan konsumsi energi dunia ini disebabkan beberapa hal, antara lain pertambahan penduduk dunia, perkembangan ilmu pengetahuan dan teknologi serta pertumbuhan berbagai macam industri. Pertumbuhan penduduk Indonesia pada saat ini sangat cepat tetapi tidak diimbangi dengan kebutuhan energi khususnya energi listrik, karena pada kenyataannya kebutuhan jumlah energi setiap penduduk berbeda. Sehingga jumlah kebutuhan energi menjadi masalah utama, karena pertambahan jumlah energi tidak diimbangi dengan ketersediaan listrik.

Dengan semakin bertambah tingginya konsumsi energi, akan mempercepat pengurangan cadangan sumber energi fosil yang sampai saaat ini masih menjadi sumber energi uudah tama, karena sumber energi fosil merupakan sumber energi yang tidak dapat

diperbarui. Beban hidup masyarakat untuk energi sudah menjadi biaya tinggi. Ketersediaan listrik oleh pemerintah tidak merata dan makin hari makin mahal biayanya bagi masyarakat pedesaan. Dari beberapa fakta, listrik sebagai energi menunjukkan bahwa terjadi krisis energi di negera ini khususnya energi listrik seperti alternatif pemadaman listrik bergilir.

Untuk mengantisipasi kekurangan sumber energi karena kebutuhan energi yang semakin meningkat, berbagai negara mulai mengembangkan dan menggunakan sumber - sumber energi baru, terutama sumber - sumber energi yang dapat diperbarui (renewable energy). Sumber energi terbarukan ini memiliki kelebihan dibanding sumber energi fosil yaitu tidak akan habis bila dikelola dengan baik dan lebih ramah lingkungan.
Sumber energi terbarukan ini ramah lingkungan sehingga dapat mengurangi limbah organik terutama limbah ternak sapi dan unggas yang banyak dipedesaan seringkali dianggap sebagai sumber masalah. Kotoran ternak selain menimbulkan bau tak sedap yang mengganggu tetangga pemilik pemilik ternak, juga dianggap sebagai sumber berbagai penyakit. Sehingga tidak jarang, pemilik ternak dalam jumlah yang banyak diprotes oleh warga sekitar, problema itu bisa diatasi dengan sistem pengelolahan limbah ternak yang manfaatnya dapat menghilangkan bau tak sedap, selain dapat menghasilkan biogas untuk kebutuhan rumah tangga dan pupuk bokasi untuk lahan pertaniannya.

Kandungan utama dalam biogas adalah metana dan karbon dioksida. Energi biogas sangat potensial untuk dikembangkan karena produksi biogas peternakan ditunjang oleh kondisi yang kondusif dari perkembangan dunia peternakan sapi di Indonesia saat ini. Disamping itu, kenaikan tarif listrik, kenaikan harga LPG (Liquefied Petroleum Gas), premium, minyak tanah, minyak solar, minyak diesel dan minyak bakar telah mendorong pengembangan sumber energi alternatif yang murah, berkelanjutan dan ramah lingkungan.

Banyak penelitian tentang biogas yang sudah dilakukan. Syamsuri, dkk (2015) melakukan penelitian tentang analisa performansi dari kompor biogas dengan variasi type burner untuk kapasitas biogas $1 \mathrm{~m}^{3} /$ hari. Variasi penelitian pada riset ini adalah: burner type regular, burner type cyclone 1 , dan burner type cyclone 2 . Hasil penelitian menunjukkan bahwa burner cyclone type 2 menghasilkan uap yang lebih banyak dari type yang lain. Penelitian tentang biogas yang lain salah satunya tentang pengaruh variasi $\mathrm{pH}$ terhadap performansi. $\mathrm{pH}$ sangat berpengaruh dalam kegagalan pada reaktor biogas 
dikarenakan tidak seimbangnya populasi bakteri metan terhadap bakteri asam yang menyebabkan lingkungan menjadi sangat asam $(\mathrm{pH}<7)$ yang selanjutnya menghambat kelangsungan hidup bakteri metan. Keasaman substrat biogas dianjurkan untuk berada pada rentang pH 6,5-8. Bakteri metan ini juga cukup sensitif dengan temperatur. Temperatur $35^{\circ} \mathrm{C}$ diyakini sebagai temperatur optimum untuk perkembanganbiakan bakteri metan [1].

\section{METODE PENELITIAN}

Gambar 1 menjelaskan tentang alur penelitian. Pembuatan rancangan alat biogas dalam tahap ini mulai dilakukan pembuatan rancangan alat biogas sesuai spesifikasi desain yang telah dibuat. pengambilan data yang sudah disiapkan berupa tabel pengujian seperti pengujian arus listrik, tegangan, putaran generator, yang divariasikan dengan variasi $\mathrm{pH} 6.8$, 7, 7.2, 7.4, 7.6, 7.8, 8 dan pembebanan menggunakan alat ukur tangampere, tachometer, dan multitester untuk mendapatkan data yang dibutuhkan. Analisa data tahap ini data yang sudah di-input kemudian diolah untuk mendapatkan data-data selanjutnya seperti tekanan efektif rata-rata, torsi dan effisiensi total sistem serta grafik yang di dapat.

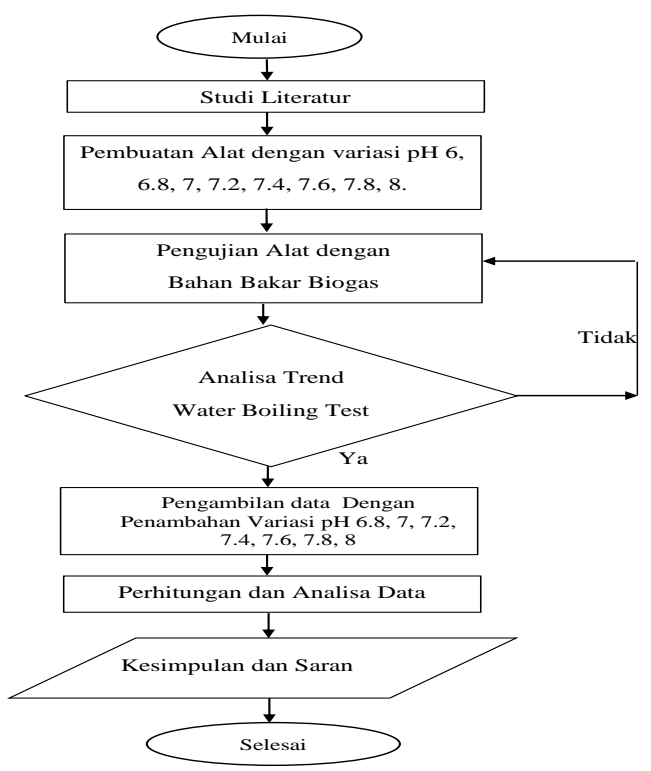

Gambar 1. Diagram Alur

\section{HASIL DAN PEMBAHASAN}

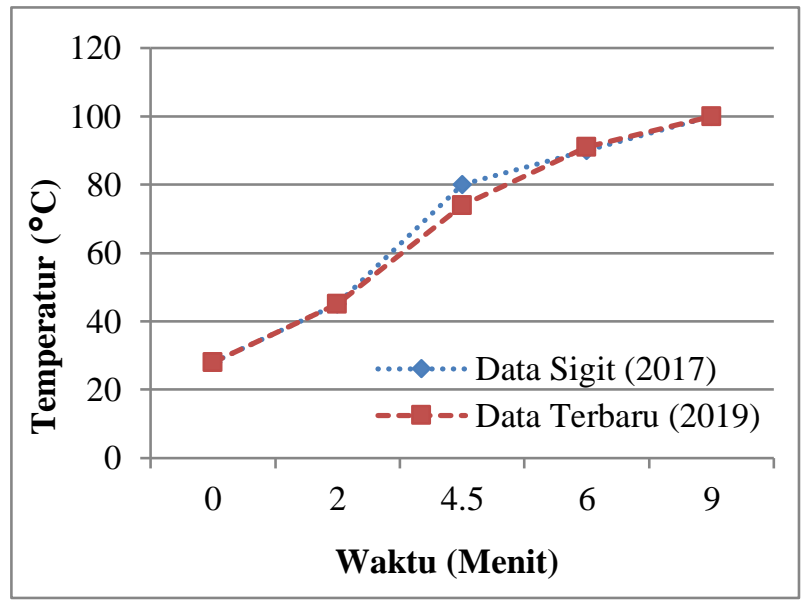

Gambar 2. Hubungan Antara Waktu terhadap Temperatur Dari Hasil Validasi

Gambar 2 adalah gambar hubungan antara waktu terhadap temperatur dari hasil validasi dengan data [2]. Secara umum terlihat bahwa dengan bertambahnya waktu maka temperatur yang dihasilkan semakin naik. Menurut teori tentang panas, panas sensibel dengan pers. 7. Jika Q yang diberikan ke air semakin besar, maka $\Delta \mathrm{T}$ juga semakin besar. Jika dibandingkan dengan data penelitian Sigit [2], maka penelitian ini memiliki kesamaan tren dan selisihnya adalah $1,7 \%$.

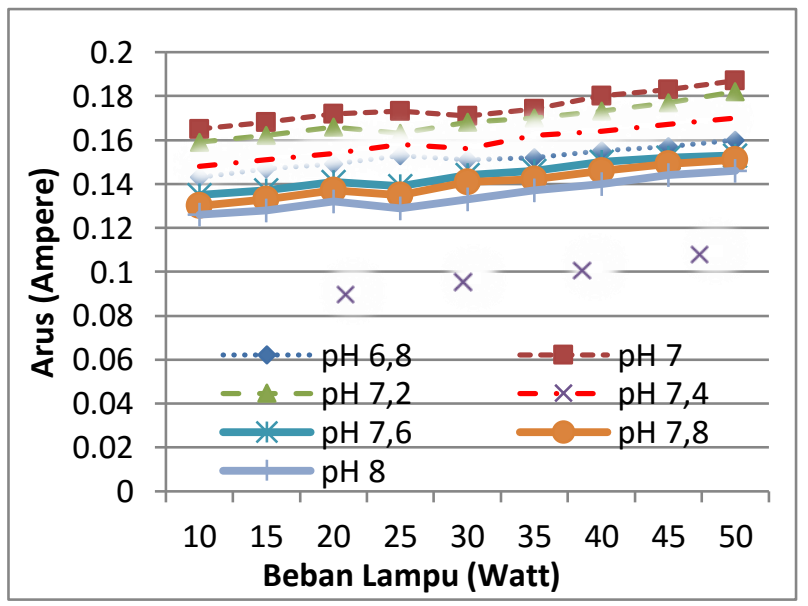

Gambar 3. Hubungan Antara Beban

Lampu Terhadap Arus Listrik yang dihasilkan Variasi pH Slurry 
Gambar 3 menunjukkan pengaruh beban lampu terhadap arus listrik dalam berbagai variasi $\mathrm{pH}$ Slurry yang dihasilkan pada generator set. Secara umum terlihat bahwa ketika beban bertambah besar maka arus listrik juga bertambah besar. Hal ini disebabkan karena beban lampu dan arus listrik berbanding lurus, jadi bila beban lampu semakin besar maka maka daya listrik yang dihasilkan juga besar. sesuai dengan Rumus $\mathrm{P}=\mathrm{V}$.I otomatis arus yang dihasilkan juga besar.

Jika dibandingkan dengan $\mathrm{pH} 6.8,7$, 7.2, 7.4, 7.6, 7.8, 8 maka $\mathrm{pH} 7$ menghasilkan arus listrik yang lebih besar dari pada $\mathrm{pH}$ lainnya [3]. Dimana pada $\mathrm{pH} 7$ ini, bakteri penghasil metana dapat berkembang dan bekerja secara optimum untuk menghasilkan biogas yang lebih baik kualitasnya.

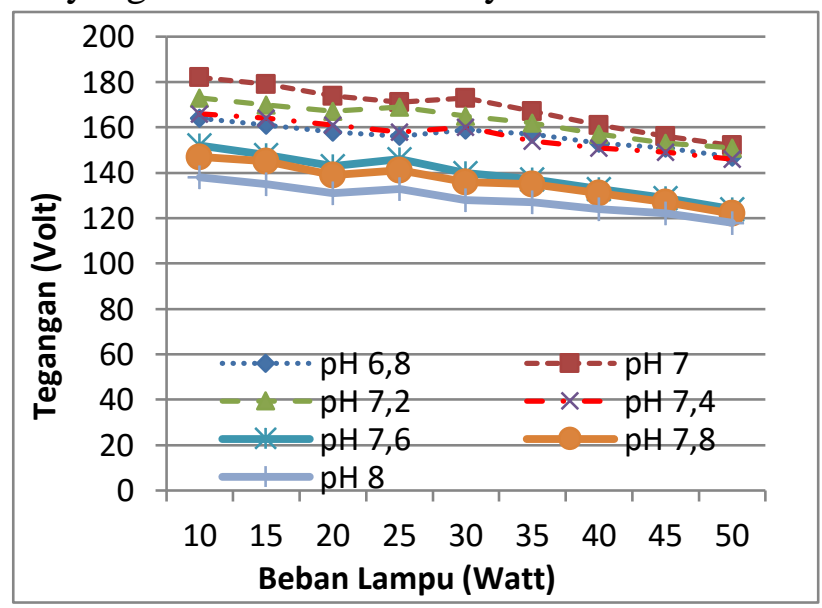

Gambar 4. Hubungan Antara Beban Lampu Terhadap Tegangan Listrik Yang dihasilkan Variasi pH slurry

Gambar 4 menunjukkan pengaruh beban lampu terhadap tegangan listrik terhadap berbagai variasi $\mathrm{pH}$. Secara umum terlihat bahwa ketika beban bertambah besar, maka tegangan listrik yang dihasilkan semakin rendah dikarenakan daya listrik yang diserap oleh beban tersebut [3].

Jika dibandingkan dengan $\mathrm{pH}$ Slurry $6.8,7,7.2,7.4,7.6,7.8$,8, maka $\mathrm{pH} 7$ Slurry menghasilkan tegangan listrik yang lebih tinggi dibandingkan $\mathrm{pH}$ Slurry lainnya.

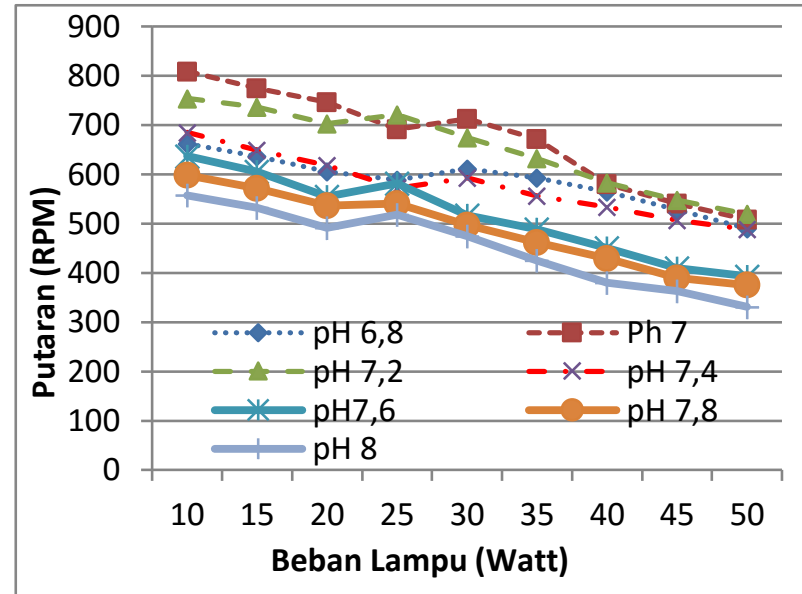

Gambar 5 Hubungan Antara Beban

Lampu Terhadap Putaran kerja mesin yang dihasilkan Variasi pH Slurry

Gambar 5 menunjukkan pengaruh beban lampu terhadap putaran mesin, dari gambar diatas terlihat bahwa generator set diberi beban lampu yang semakin besar, maka putaran yang dihasilkan semakin berkurang [3]. Ada hal lain yang menarik disini $\mathrm{pH} 7$ dari slurry biogas menghasilkan putaran yang lebih besar dibandingkan dengan $\mathrm{pH}-\mathrm{pH}$ lainnya. Hal ini berkesesuaian dengan penelitian Fazri Azhori dkk (2015).

Hasil dari penelitian ini mengetahui bahwa semakin besar mikrooganisme tumbuh dibawah kandungan $\mathrm{pH}$ netral, karena nilai $\mathrm{pH}$ memiliki dampak yang kurang baik bagi metabolisme yang akan mengubah reaksi kimia enzimatis, atau merusak enzim.

Kelompok bakteri metanaogenik sangat sensitif terhadap $\mathrm{pH}, \mathrm{pH}$ rendah akan menyebabkan reaksi rantai kimia dalam pencernaan terhenti [4]. Nilai $\mathrm{pH}$ yang terlalu tinggi harus dihindari karena akan menyebabkan produk akhir yang dihasilkan adalah $\mathrm{CO}_{2}$ sebagai produk utama (Beni dkk, 2007).

Gambar 6 Hubungan Antara Beban Lampu Terhadap Tekanan Efektif Yang dihasilkan oleh variasi $\mathrm{pH}$ 


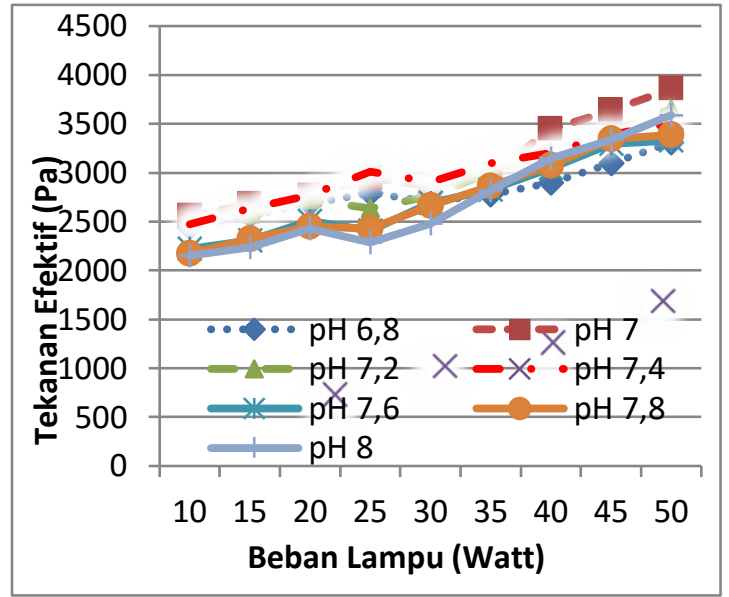

Gambar 6 menunjukkan pengaruh beban lampu terhadap tekanan efektif pada generator set. Secara umum terlihat bahwa dengan beban yang semakin besar maka tekanan efektif juga semakin besar. Hal ini berdasarkan teori yang ada dalam Pers. 4

Dari data yang diperoleh ada sesuatu yang menarik yakni pH 7 menghasilkan tekanan efektif paling tinggi dari variasi kadar pH lainnya.

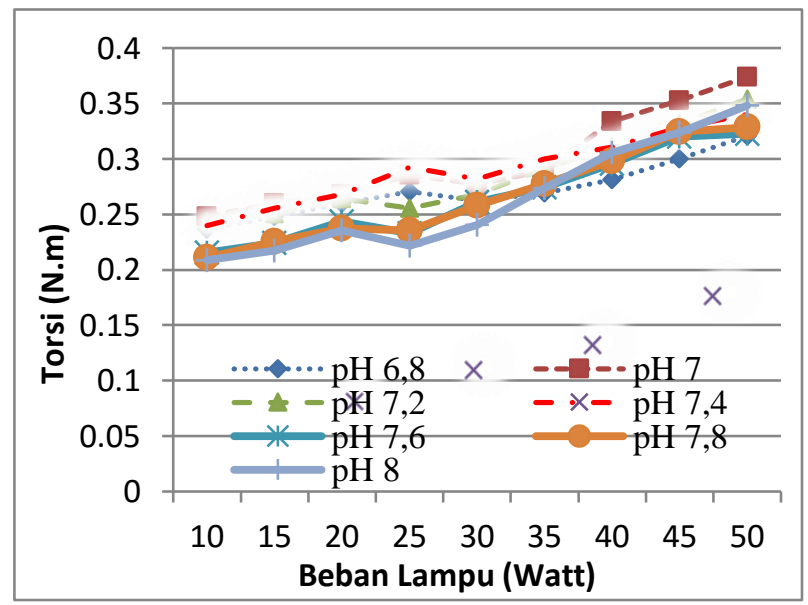

Gambar 7 Hubungan Antara Beban

Lampu Terhadap Torsi yang dihasilkan Variasi pH Slurry

Gambar 7 menunjukkan pengaruh beban lampu terhadap torsi generator set. Secara umum terlihat bahwa dengan bertambahnya beban listrik maka torsi semakin besar. Hubungan torsi dengan putaran mesin dan daya efektif secara matematik sebagaimana pers. 1

Jika dibandingkan dengan variasi $\mathrm{pH}$ $6.8,7,7.2,7.4,7.6,7.8,8$ maka $\mathrm{pH} 7$ menghasilkan torsi lebih tinggi dibandingkan dengan torsi pada kadar variasi $\mathrm{pH}$ lainnya.

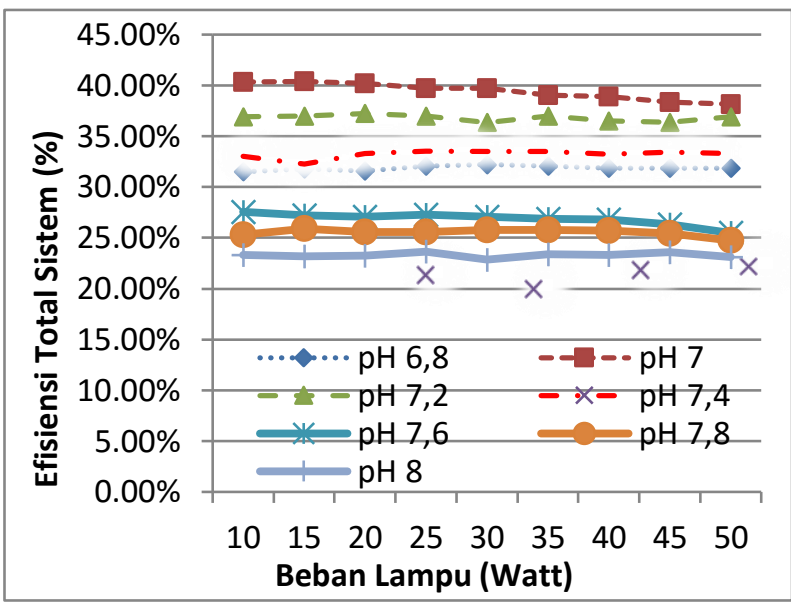

Gambar 8 Hubungan Beban Lampu terhadap Efisiensi Total Sistem yang dihasilkan Variasi pH Slurry

Gambar 8 menunjukkan pengaruh beban lampu terhadap efisiensi total sistem. Pada umumnya jika geneator set diberi beban lebih besar maka efisiensi sistem agak naik, dari grafik diatas menunjukkan bahwa efisiensi sistem sedikit naik cenderung stabil hal ini karena adanya pengaruh pada reaksi kimia dari $\mathrm{NaOH}$, Sehingga dari data yang diperoleh diketahui bahwa variasi kadar pH 7 slurry lebih stabil dan hasil akhirnya lebih tinggi bila dibandingkan dengan variasi kadar $\mathrm{pH}$ lainnya.

Hasil penelitian ini mengetahui bahwa sebagian besar mikroorganisme tumbuh dibawah kandungan $\mathrm{pH}$ netral, karena nilai $\mathrm{pH}$ memiliki dampak yang kurang baik bagi metabolism yang akan mengubah reaksi kimia enzimatis, atau merusak enzim. Kelompok bakteri metanaogenik sangat sensitive terhadap $\mathrm{pH}, \mathrm{pH}$ rendah akan menyebabkan reaksi rantai kimia dalam pencernaan terhenti (gunnerson, dkk,1986).

Sehingga dari data yang diperoleh diketahui bahwa variasi kadar $\mathrm{pH} 7$ slurry lebih stabil dan hasil akhirnya lebih tinggi bila dibandingkan dengan variasi kadar $\mathrm{pH}$ lainnya. 


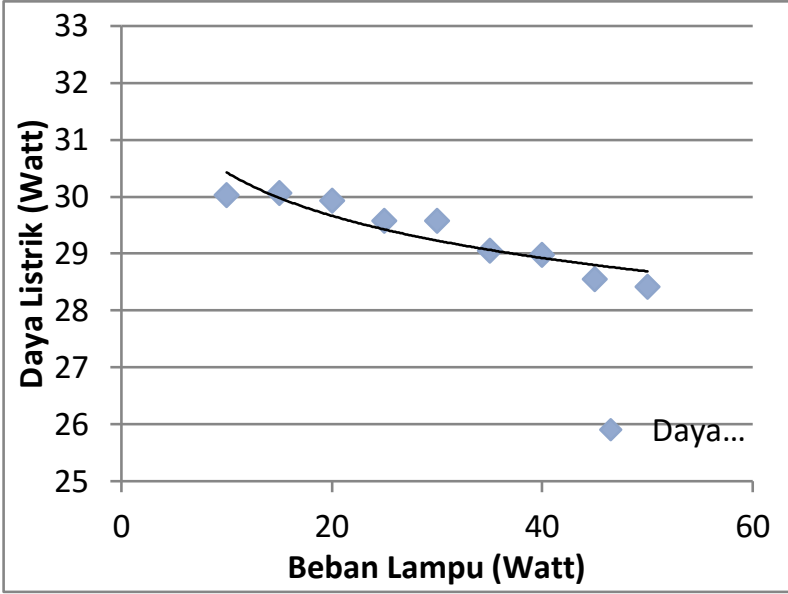

Gambar 9 Hubungan Antara Beban

Lampu Terhadap Daya Listrik Yang

Dihasilkan

Gambar 9 adalah gambar hubungan antara beban lampu terhadap daya listrik khusus untuk $\mathrm{pH}$ 7. Secara umum terlihat bahwa dengan semakin bertambahnya beban lampu maka daya listrik semakin turun.

Sebagai contoh, ketika beban lampu 10 watt maka menghasilkan daya listrik 30 watt begitu seterusnya semakin besar beban lampu maka semakin kecil daya listrik yang dihasilkan sampai dengan beban lampu 50 watt menghasilkan daya listrik sekitar 20 watt.

\section{KESIMPULAN}

Kesimpulan penelitian ini diperoleh bahwa effisiensi secara umum jika beban listrik semakin besar maka effisiensi sistem cenderung stabil, kadar $\mathrm{pH} 7$ menghasilkan effisiensi lebih baik dari pada $\mathrm{pH}$ slurry lainnya. Untuk $\mathrm{pH} 7$, dengan bertambahnya beban lampu maka daya listrik yang dihasilkan semakin kecil. Secara umum, terlihat bahwa dengan beban lampu yang semakin besar maka torsi yang dihasilkan juga besar. $\mathrm{pH} 7$ memiliki torsi yang lebih besar dibandingkan dengan $\mathrm{pH}$ lainnya.

\section{UCAPAN TERIMAKASIH}

Terima kasih kepada ITATS yang telah mendanai penelitian ini sehingga penelitian ini bisa sampai selesai.

\section{REFERENSI}

[1] Beni Hermawan, Lailatul Qodriyah, dan Candrarini Puspita, 2007. Pemanfaatan sampah organik sebagai sumber biogas untuk mengatasi krisis energi dalam negeri. Karya Tulis Ilmiah Universitas Lampung, Bandar Lampung.

[2] Fajri Azhari, Bunda Halang, Muhammad Zaini . 2015. Kualitas biogas yang dihasilkan dari substrat kotoran sapi dan penambahan starter buah-buahan dengan menggunakan digester kubah, Jurnal Wahana-Bio, Volume XIV, 68-91.

[3] Gita Khaerunnisa dan Ika Rahmawati . 2013. Pengaruh ph dan rasio cod:n terhadap produksi biogas dengan bahan baku limbah industri alkohol (vinasse), Jurnal Teknologi Kimia dan Industri, Vol. 2, No. 3, 17.

[4] Gunerson CG dan Stuckey DC. 1986. Anaerobic Digestion : Principles and Practices for Biogas System, Washington, D.C: The World Bank Washington.

[5] Harsono. 2013. Pusat Informasi dokumentasi PTP-ITB.F.

[6] Santoso B. 2015. Pengaruh variasi kadar pH slurry biogas terhadap efisiensi generator set, Skripsi Institut Teknologi Adhi Tama Surabaya.

[7] Sigit Setiawan . 2017. Pengaruh variasi nutrisi $\mathrm{NaOH}$, Urea \& Rumen terhadap performa generator berbahan bakar biogas, Skripsi Institut Teknologi Adhi Tama Surabaya.

[8] Syamsuri, Suheni and Yustia W. M. 2015. Performance analysis of biogas stoves with variations of flame burner for the capacity of biogas $1 \mathrm{~m} 3$ / day, ARPN Journal of Engineering and Applied Sciences, Vol. 10, N0. 22, 10349-10353. 